\title{
BUSANA DAN KECANTIKAN : WACANA PENGEMBANGAN PRODI MENUJU PENDIDIKAN PARIWISATA
}

\author{
Agus Hery Supadmi Irianti \\ agushery_um52@yahoo.co.id \\ Dosen Pendidikan Tata Busana Teknologi Industri FT- UM
}

\begin{abstract}
Abstrak. Saat ini perkembangan pariwisata cukup signifikan peningkatannya. Berbicara masalah sector pariwisata tidak dapat dipisahkan oleh bidang lain yang terkait, karena dalam sector pariwisata akan terkait satu dengan lainnya. Data peningkatan itu tersirat dalam data Wisatawan Nusantara dan Wisatawan Manca Negara. Dari hasil penelitian di kota Malang, Pariwisata Malang juga menyumbangkan retribusi pendapatan asli daerah sebesar $0,08 \%$ " Jadi, dapat dikata kan bahwa potensi retribusi pariwisata dalam menyumbang PAD Kota Malang adalah sebesar $0,08 \%$ "Walau tidak cukup besar. Penelitian lain juga menunjukkan terdapat kontribusi pendapatan yang lebih besar dari anggota rumah tangga terhadap pendapatan rumah tangga Hal ini disebabkan bertambahnya anggota rumah tangga yang memperoleh kesempatan kerja di sektor pariwisata. Prodi S1 Pendidikan Tata Busana dan Prodi D3 Tata Busana memiliki ciri khas yang tidak dimiliki prodi serumpun yang lainnya dalam kurikulumnya. Ciri khas tersebut adalah pendidikan kewira usahaan. Ini artinya dunia wira usaha erat kaitannya dengan bisnis dan bisnis adalah bagian dari pariwisata. Metode untuk mewujudkan gagasan adalah sbb: 1)Kejelasan Konsep arah pengembangan menuju Pendidikan Pariwisata, karena hal ini akan menjadi pijakan dalam mengembangkan wacana pendidikan Pariwisata.2) Kajian kurikulum, yang relevan dengan konsep yang dikembangkan, 3) Penyiapan sumber daya manusia, dapat disiapkan melalui tahapan tahapan studi banding, pelatihan dan magang secara bertahap, dan jika diperlukan adalah perekrutan tenaga yang ahli dibidangnya, 4) Persiapan laboratorium yang menunjang konsep Pendidikan Pariwisata dan terakhir 5) Memiliki semangat dan kemauan yang tinggi untuk merealisasikan.
\end{abstract}

Kata Kunci: Busana, Kecantikan, Wacana, Pendidikan Pariwisata.

\section{PENDAHULUAN}

\section{Perkembangan Pariwisata}

Telah kita ketahui bahwa perkembangan pariwisata memberikan arti yang sangat positif bagi Negara kita. Dampak yang ditimbulkan dari sector pariwisata ini sungguh luar biasa. Perkembangan dari tahun ke tahun semakin meningkat, walau pernah mengalami kemerosotan akibat kasus Bom Bali yang mengguncang negara kita beberapa waktu yang lalu. Saat ini perkembangan pariwisata cukup signifikan peningkatannya. Berbicara masalah sector pariwisata tidak dapat 
dipisahkan oleh bidang lain yang terkait, karena dalam sector pariwisata akan terkait satu dengan lainnya, misalanya masalah tujuan wisata akan berpengaruh pada penginapan, makanan, cindera mata, transportasi dan masih banyak lainnya yang memiliki hubungan timbale balik, bahkan masalah pariwisata akan berimbas pada penyerapan tenaga kerja dan pendapatan daerah. Data peningkatan itu tersirat dalam data Wisatawan Nusantara dan Wisatawan Manca Negara yang terus meningkat. Berikut ini data Wisatawan manca Negara pada dua tahun terakhir

\section{JUMLAH KUNJUNGAN WISATAWAN MANCA NEGARA MENURUT ASAL WISATAWAN TAHUN 2010-2011}

\begin{tabular}{|r|l|r|r|r|}
\hline No & $\begin{array}{l}\text { NEGARA ASAL } \\
\text { WISATAWAN }\end{array}$ & $\begin{array}{c}\text { JML } \\
\text { WISATAWAN } \\
\mathbf{2 0 1 0}\end{array}$ & $\begin{array}{c}\text { JML } \\
\text { WISATAWAN } \\
\mathbf{2 0 1 1}\end{array}$ & $\begin{array}{r}\text { TINGKAT } \\
\text { PERTUMBUHAN }\end{array}$ \\
\hline 1 & Singapura & 77.934 & 94.879 & 22.74 \\
\hline 2 & Malaysia & 62.647 & 74.606 & 19.09 \\
\hline 3 & Jepang & 40.120 & 43.293 & 7.91 \\
\hline 4 & Korea Selatan & 18.955 & 21.590 & 13.90 \\
\hline 5 & Taiwan & 15.437 & 18.531 & 20.04 \\
\hline 6 & China & 31.929 & 43.964 & 37.69 \\
\hline 7 & India & 9.847 & 12.489 & 26.83 \\
\hline 8 & Philipina & 8.027 & 10.049 & 25.19 \\
\hline 9 & Hongkong & 4.111 & 5.565 & 35.37 \\
\hline 10 & Thailand & 4.888 & 6.948 & 42.14 \\
\hline 11 & Australia & 70.513 & 89.375 & 26.75 \\
\hline 12 & Amerika Serikat & 13.016 & 15.693 & 20.57 \\
\hline 13 & Inggris & 16.047 & 17.559 & 9.42 \\
\hline 14 & Belanda & 14.692 & 15.874 & 8.05 \\
\hline 15 & Jerman & 14.690 & 15.743 & 7.17 \\
\hline 16 & Perancis & 13.481 & 14.652 & 8.69 \\
\hline 17 & Rusia & 4.874 & 4.849 & -0.51 \\
\hline 18 & Arab Saudi & 9.446 & 10.322 & 9.27 \\
\hline 19 & Mesir & 240 & 336 & 40.00 \\
\hline 20 & Uni Emirat Arab & 350 & 479 & 36.86 \\
\hline 21 & Bahrain & 55 & 132 & 2.48 \\
\hline 22 & Negara lainnya & 91.352 & 93.617 & $\mathbf{1 6 . 8 2}$ \\
\hline & & $\mathbf{5 2 2 . 6 5 1}$ & $\mathbf{6 1 0 . 5 4 4}$ & \\
\hline
\end{tabular}

Sumber: Ditjen Imigrasi dan BPS ( diolah kembali oleh PusdatinKemenbudpar)

Catatan: Data tahun 2011 merupakan data sementara

Sedangkan data perkembangan wisatawan Nusantara, adalah sebagai berikut: 
Perkembangan Wisatawan Nusantara (WISNUS) Tahun 2004 - 2010.

\begin{tabular}{|l|l|l|l|l|}
\hline TAHUN & $\begin{array}{l}\text { WISNUS } \\
\text { (ribuan orang) }\end{array}$ & $\begin{array}{l}\text { PERJALANAN } \\
\text { (ribuan) }\end{array}$ & $\begin{array}{l}\text { RATA-RATA } \\
\text { PERJALANAN } \\
\text { (hari) }\end{array}$ & $\begin{array}{l}\text { TOTAL } \\
\text { PENGELUARAN } \\
\text { (triliun Rp) }\end{array}$ \\
\hline 2004 & 111.352 & 202.763 & 1,82 & 71,70 \\
\hline 2005 & 112.701 & 198.359 & 1,76 & 74,72 \\
\hline 2006 & 114.270 & 204.553 & 1,79 & 88,21 \\
\hline 2007 & 115.335 & 222.389 & 1,93 & 108,96 \\
\hline 2008 & 117.213 & 225.041 & 1,92 & 123,17 \\
\hline 2009 & 119.944 & 229.731 & 1,92 & 137,91 \\
\hline 2010 & 122.312 & 234.377 & 1,92 & 150,49 \\
\hline
\end{tabular}

Sumber : BPS (diolah kembali oleh P2DSJ)

Dari hasil penelitian di kota Malang, Pariwisata Malang juga menyumbangkan retribusi pendapatan asli daerah sebesar $0,08 \%$ " Jadi, dapat dikata kan bahwa potensi retribusi pariwisata dalam menyumbang PAD Kota Malang adalah sebesar 0,08\%"Walau tidak cukup besar ( Putra Dani Surya, 2010). Penelitian lain juga menunjukkan terdapat kontribusi pendapatan yang lebih besar dari anggota rumah tangga terhadap pendapatan rumah tangga Hal ini disebabkan ber-tambahnya anggota rumah tangga yang memperoleh kesempatan kerja di sektor pariwisata (Sudiarditha I Ketut dkk, 2008). Mc Kean (1973:26) menyatakan : "tourism is very much a part of the modern tradition, but it is built on the foundation laid during the little and great tradition, without which it would never been started and without which it will not florish in the future". Pariwisata kota sudah tentu selain memberikan manfaat baik secara pencitraan dan financial bagi kehidupan masyarakat juga dapat memberikan peluang kepada masyarakat sekitar kampus untuk memperoleh akses kemanfaatan dengan cara turut berpartisipasi dalam hal produk wisata. Dalam peringatan hari pariwisata yang jatuh pada tanggal 27 September yang ditetapkan oleh World Tourism Organization (UNWTO) bertujuan untuk mendorong kesadaran masyarakat internasional akan pentingnya pariwisata sebagai bagian dari pembangunan sosial, budaya, ekonomi, yang berkelanjutan. (Wacik Jero, 2011).

\section{Pendidikan Pariwisata}

Tidak salah jika pariwisata ditangkap sebagai peluang usaha yang memiliki prospek. Daerah daerah berlomba untuk mengemas obyek dan tujuan wisata yang dapat memberikan daya tarik bagi wisatawan. Demikian juga dunia pendidikan juga menangkap ini sebagai peluang yang memiliki prospek yang bagus di masa mendatang menginggat Memasuki 2011 pengangguran terbuka sekarang ada pada angka 9,25 juta. . Sehingga pariwisata adalah bisnis yang tepat hal ini terbukti dengan menjamurnya pendidikan kepariwisataan di Indonesia, 
bahkan lembaga lembaga penyelenggara pendidikan pariwisata tidak hanya dari kalangan pendidikan saja, kalangan usahawan yang memiliki fasilitas yang memadai di bidang pariwisata juga menyelenggarakan. Mulai dari Akademi Pariwisata, Sekolah Tinggi Pariwisata hingga Pendidikan singkat. Namun dari begitu banyaknya pendidikan pariwisata, semua cenderung pada bidang perhotelan atau biro perjalanan, Saat ini belum ada satupun pendidikan pariwisata bidang busana dan kecantikan. Yang ada hanyalah busana dan kecantikan yang pendidikannya bertaraf internasional. Jika ini ( Busana dan Kecantikan ) digagas untuk pengembangan prodi ke arah pariwisata, maka hal ini tentu sejalan dengan Peraturan Pemerintah Republik Indonesia Nomor 23 Tahun 2005 Tentang Pengelolaan Keuangan Badan Layanan Umum, .Dimana pasal 1 ayat 12dijelaskan bahwa Praktek bisnis yang sehat adalah penyelenggaraan fungsi organisasi berdasarkan kaidah-kaidah manajemen yang baik dalam rangka pemberian layanan yang bermutu dan berkesinam bungan.

\section{Potensi Busana dan Kecantikan menuju Pendidikan Pariwisata}

Saat ini Jurusan TI, memiliki prodi S1 Pendidikan Tata Busana, Prodi D3 Tata Busana, serta Tata Boga dan Pendidikan Tata Boga . Pada prodi S1 Pendidikan memiliki visi misi sebagai berikut: Visi S1 Pendidikan Tata Busana adalah Menjadi lembaga pendidikan tinggi Pendidikan Tata Busana yang dapat menyiapkan peserta didik yang bertaqwa kepada Tuhan Yang Maha Esa, jujur, bertanggung jawab, cerdas, memiliki pengetahuan, keterampilan, dan kemampuan profesional ipteks dalam bidang busana, serta memiliki keunggulan kompetitif dan mampu menjadi tolok ukur bagi pendidikan tinggi kebusanaan di Indonesia yang berorientasi pada pemenuhan kebutuhan masyarakat. Sedangkan misinya adalah menyelenggarakan pendidikan profesi pendidik pada bidang tata busana (S1) yang berorientasi pada dunia pendidikan yang menghasilkan:

a. Sumber Daya Manusia (SDM) yang memiliki pengetahuan bidang studi tata busana yang berkualitas dan dapat dipertanggung jawabkan sesuai dengan kebutuhan dunia pendidikan.

b. SDM yang mampu memahami perkembangan peserta didik dalam upaya peningkatan pembelajaran dan pembentukan kepribadian yang mandiri

c. SDM yang memahami konsep dasar seorang pendidik dan dapat menerapkan serta melaksanakan proses pembelajaran serta mampu mengembangkan bidang studi tata busana melalui penelitian dan karya akademik lain yang berbobot dan bermakna.

d. SDM yang memiliki kepribadian yang kuat dan tangguh dan keprofesionalan sebagai seorang pendidik.

Adapun Kompetensi utama yang diharapkan dimiliki lulusan program S1 Pendidikan Tata Busana adalah mampu mempresentasikan diri sebagai pendidik SMK di bidang busana, pengelola dan praktisi lapangan dalam dunia pendidikan yang berkualitas, tangguh dan kompetitif. Kompetensi pendukung yang disiapkan lulusan S1 Pendidikan Tata Busana adalah memiliki kemampuan profesional di bidang busana, yang memiliki orientasi bisnis di masa depan, memiliki gagasangagasan dan kreativitas yang dapat menunjang perkembangan usaha busana; sebagai pengelola usaha di bidang usaha busana yang tangguh, berkepribadian, 
dan mampu menghargai sesama manusia; mampu melakukan penelitian potensi unggulan daerah yang spesifik, dan mampu mengembangkan potensi sumberdaya manusia lokal.

\section{Kompetensi Lulusan S1 Pendidikan Tata Busana}

1) Kompetensi:

a) Memiliki kemampuan sebagai tenaga kependidikan pada bidang busana sebagaimana tertuang dalam PP 19 tahun 2005 dan SGKP SMK

(1) memahami teori belajar dan mengajar

- Memahami ciri-ciri dan perkembangan peserta didik

- Memahami dan melaksanakan kependidikan bagi peserta didik

- Memahami prinsip-prinsip dan cara-cara belajar serta implikasinya dalam proses pembelajaran

- Memahami berbagai teknik evaluasi dan penggunaannya dalam proses pendidikan dalam bidang busana, baik aspek teori dan keterampilannya

b) Memiliki kemampuan bidang busana secara teori dan praktik

(2) memiliki kemampuan bidang busana secara teori dan praktik

(3) memahami teori belajar dan mengajar

- Memahami ciri-ciri dan perkembangan peserta didik

- Memahami dan melaksanakan kependidikan bagi peserta didik

- Memahami prinsip-prinsip dan cara-cara belajar serta implikasinya dalam proses pembelajaran

- Memahami berbagai teknik evaluasi dan penggunaannya dalam proses pendidikan dalam bidang busana, baik aspek teori dan keterampilan

c) Memiliki ketrampilan mengajar dalam bidang busana

(4) Memiliki ketrampilan mengajar dalam bidang busana

Adapun Visi Prodi D3 Tata busana adalah terwujudnya Prodi D3 Tata Busana Sebagai pusat keunggulan dan lembaga rujukan penyelenggara pendidikan, penelitian, dan penerapan ilmu serta teknologi dalam bidang Busana yang relevan dengan kebutuhan pembangunan, masyarakat, serta kemanusiaan. Adapun misinya adalah:(1) Menghasilkan Sumber Daya Manusia (SDM) yang berkualitas di bidang Busana sesuai dengan kebutuhan dunia usaha/industri, dan kebutuhan pembangunan, dengan menerapkan system pendidikan yang efektif, efisien dan fleksibel. (2) Mengembangkan ilmu pengetahuan dan teknologi Busana melalui kegiatan penelitian dan pengembangan yang menghasilkan karya akademik dan temuan-temuan yang berbobot dan bermakna. (3) menerapkan ilmu pengetahuan dan teknologi Busana yang berguna bagi kesejahteraan masyarakat dan kemanusiaan. (4) Menjadi pusat informasi dalam bidang pengembangan teknologi Busana dan kewirausahaan berbasis teknologi Busana. (5) Mengembangkan kerja sama dengan lembaga, baik di dalam maupun diluar UM dalam rangka pengembangan pendidikan, penelitian maupun pengabdian kepada masyarakat di bidang Tata Busana.

Adapun kompetensi lulusan D3 tata busana adalah: 
a. Supervisor Industri Busana (1)Memiliki kemampuan menggunakan alat jahit dengan tepat (2) Memiliki pengetahuan memilih bahan (3) Memiliki kemampuan membuat desain (4)Memiliki kemampuan membuat pola busana (konstruksi standart) (5) Memiliki kemampuan membuat pola secara grading (6) Memiliki kemampuan memotong bahan sesuai pola., menjahit sesuai model, packing dan labeling (7) Memiliki kemampuan menghias kain/busana (8) Memiliki kemampuan membuat pelengkap busana (9) Memiliki kemampuan tentang Pengetahuan dan keterampilan K3 (10) Memiliki kemampuan melakukan komunikasi dengan baik(11)Memiliki kemampuan tentang kepengawasan (supervisi) pada perencanaan produksi, proses dan pengendalian mutu.

b. Pengelola Usaha Busana, yaitu pengelola usaha modiste, pengelola usaha industri, pengelola usaha butik Pengelola Usaha busana memiliki (1)pengetahuan tentang manajemen (2) Memiliki kemampuan mengelola usaha busana industri (3) Memiliki kemampuan mengelola usaha busana modiste/tailor (4) Memiliki kemampuan mengelola usaha busana butik

c. Instruktur Bidang Busana (1) Memiliki kemampuan melakukan komunikasi dengan baik (2) Memiliki Kemampuan dan Ketrampilan menyampaikan materi bidang busana (Katalog TI, 2010)

Sedangkan untuk kecantikan memang di Jurusan TI tidak memiliki prodi tersebut, namun dalam mata kuliah dasar tatarias diberikan sebagai penunjang dalam prodi S1 Pendidikan Tata Busana dan dan prodi D3 Tata Busana. Selain itu dimilikinya laboratorium tatarias dan dosen bidang keahlian tata rias merupakan modal untuk mengembangkan kearah sana. Dari uraian di atas sangat jelas, bahwa banyak materi dalam dua prodi tersebut yang potensial menghasilkan produk yang dapat menunjang gagasan prodi sebagai pendidikan pariwisata. Hal ini dilandasi bahwa kurikulum yang ada di Prodi tersebut memiliki cirri khas yang tidak dimiliki prodi serumpun yang lainnya. Ciri khas tersebut adalah pendidikan kewira usahaan. Ini artinya dunia wira usaha erat kaitannya dengan bisnis dan bisnis adalah bagian dari pariwisata. Inilah yang membuat penulis optimis, karena Jenis - jenis wisata ini dapat berkembang lebih banyak tergantung pada kondisi dan situasi perkembangan dunia kepariwisataan di suatu daerah atau suatu negara. Makin kreatif dan banyak gagasan yang dimiliki oleh mereka yang mendedikasikan hidup mereka bagi perkembangan dunia kepariwisataan di dunia ini, makin bertambah pula bentuk dan jenis wisata yang dapat diciptakan bagi kemajuan industri ini ( Wisnawa, 2011).

\section{PERMASALAHAN}

Bagaimana menyiapakan Busana dan Kecantikan sebagai gagasan pengembangan prodi menuju pendidikan Pariwisata?

\section{METODE}

Untuk mewujudkan ide dan gagasan tersebut tentu tidak semudah kita membalikkan telapak tangan. Semua membutuhkan kajian yang lebih mendetail, yang jelas optimisme untuk menuju pendidikan pariwisata memiliki landasan yang rasional. Hal ini sejalan dengan kutipan berikut: Pariwisata dapat disoroti dari berbagai sudut pandang karena kekompleksitasannya. Kompleksitas yang terkandung dalam pariwisata misalnya pariwisata sebagai pengalaman manusia, pariwisata sebagai 
perilaku sosial, pariwisata sebagai fenomena geografik, pariwsata sebagai sumber daya, pariwisata sebagai bisnis, dan pariwisata sebagai industri (Wurianto, 2006). Adapun Halhal yang perlu dipersiapkan adalah sbb:

1. Kejelasan Konsep arah pengembangan menuju Pendidikan Pariwisata, karena hal ini akan menjadi pijakan dalam mengembangkan wacana pendidikan Pariwisata

2. Kajian kurikulum, yang relevan dengan konsep yang dikembangkan.

3. Penyiapan sumber daya manusia, dapat disiapkan melalui tahapan tahapan studi banding, pelatihan dan magang secara bertahap, dan jika diperlukan adalah perekrutan tenaga yang ahli dibidangnya.

4. Persiapan laboratorium yang menunjang konsep Pendidikan Pariwisata.

5. Memiliki semangat dan kemauan yang tinggi untuk merealisasikan pendidikan Pariwisata.

\section{KESIMPULAN}

Busana dan Kecantikan gagasan menuju pendidikan Pariwisata sangat memungkinkan, Hal ini dapat dilihat dari visi, misi serta kompetensi saat ini yang sudah memiliki cirri khas sebagai sesuatu yang plus dalam kurikulum Pendidikan tata Busana, yaitu Managemen kewira usahaan. Selain itu Ide dan gagasan ini mengacu pada adanya peluang di sector pariwisata yang secara nasional dan internasional member peningkatan yang pesat dan menyumbangkan devisa Negara yang cukup besar. Kekompleksitasan Pariwisata itulah yang memperkuat wacana ini, artinya sentuhan kreativitas dan ide yang mendukung kea rah pariwisata merupakan modal yang kuat untuk mewujudkan Gagasan tersebut.

\section{Kajian Pustaka}

BPS ( diolah kembali oleh Pusdatin-Kemenbudpar).2011. Data Wisatawan Nusantara dalam Nur. Jejaring Pariwisata Lokal Regional. 17 Nopember 2011

BPS ( diolah kembali oleh Pusdatin-Kemenbudpar).2011. Data Wisatawan Manca Negara tahun 2010-2011

Mc Kean, Philip Frick.1973. Cultural Involution Tourist Balinese and The Process of Modernization in Anthropological Perspective. USA: Brown University, Anthrpology Deparment

Peraturan Pemerintah Republik Indonesia Nomor 23 Tahun 2005 Tentang Pengelolaan Keuangan Badan Layanan Umum

Putra Dani Surya, 2010. Kontribusi dan optimalisasi retribusi pasar, retribusi parkir, dan retribusi pariwisata terhadap pendapatan asli daerah (PAD) Kota Malang tahun 2005-2009. Universitas negeri Malang

Sudiartha I Ketut, 2008. AGRITEK VOL. 16 NO. 8. Analisis Pengembangan Sektor Industri Pariwisata: Studi Kasus di Kabupaten Daerah Tingkat II 


\section{Karangasem Bali}

Universitas Negeri Malang. 2010. Katalog Jurusan TI Fakultas Teknik UM. Fakultas Teknik

Wacik Jero. 2011. Sambutan Menteri Kebudayaan Dan Pariwisata dalam Memperingati Hari Pariwisata Dunia 2011. Jakarta.

Wurianto Arif Budi. 2006. Alternatif Model Pengembangan Pariwisata Terpadu Kota Malang. UMM: Lembaga penelitian

Wisnawa I Made Bayu, 2011. Bentuk dan Jenis Pariwisata. 


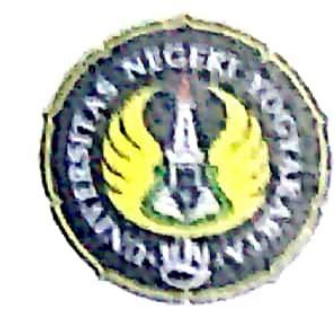

KEMENTERIAN PENDIDIKAN DAN KEBUDAYAAN

UNIVERSITAS NEGERI YOGYAKARTA

FAKULTAS TEKNIK

Alamat : Kampus Karangmalang, Yogyakarta, 55281

lelp. (0274) 586168 p5w, 276,289,292 (0274) 586734 Fax. (0274) 586734

website:http://ttuny.ac.ide-mail: ft@uny.ac.id; teknik@uny.ac.id

Certicate No. QSC 00592

\section{$\underline{S} \mathbb{E} \mathbb{R}\rceil \mathbb{N} \mathbb{F} \| \mathbb{K} \mathbb{A}\rceil \Gamma$}

Nomor: 1938/UN 34.15/PM/2011

Diberikan kepada :

\section{Dra. Agus Fery Supadmi Irianti, X.Pd.}

dengen judul "Busana dan Kecantikan: Wacana Pengembangan Prodi Menuju Pendidikan Pariwisata"

dalam Seminar Nasional Wonderful Indonesia "Wonderful People, Food, Fashion and Beauty" yang dilaksanakan pada tanggal 3 Desember 2011 di Jurusan Pendidikan Teknik Boga dan Busana FT UNY.

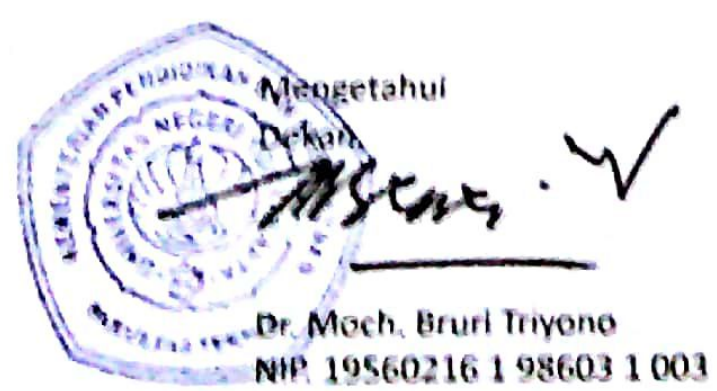

Yogyakarta, 3 Desember 2011

Ketua Panitia

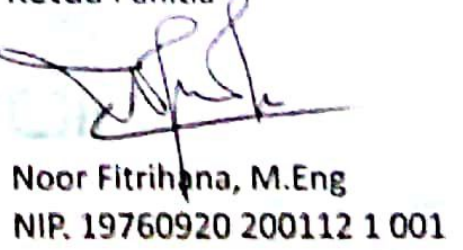

NIP. 197609202001121001 